\title{
Szczęście, czyli jak być zdrowym w kapitalizmie. Recenzja książki The Happiness Industry. How the Government and Big Business Sold Us Well-Bein
}

Tytul: The Happiness Industry. How the

Government and Big Business Sold Us Well-Bein

Autor: William Davies

The HAPPINESS

INDUSTRY

Przełożył: David Fernbach

Wydawca: Verso

Rok wydania: 2015

Liczba stron: 320

Tomasz Szymon Markiewka

Collegium Medicum

Uniwersytet Mikołaja Kopernika

markiewkatomasz@gmail.com

Przyjęto: 9 luty; zaakceptowano: 27 luty.

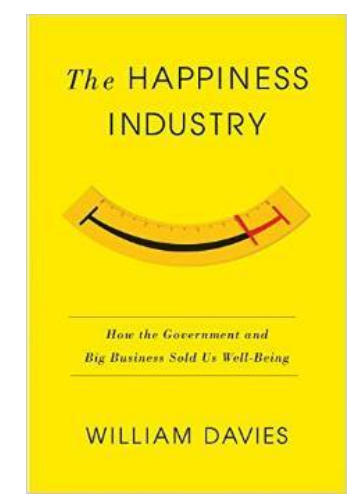

\begin{abstract}
Abstrakt
Książka Williama Daviesa The Happiness Industry. How the Government and Big Business Sold Us Well-Being jest poświęcona zagadnieniu szczęścia w perspektywie filozoficzno-socjologicznej. Autor stara się dowieść, że we współczesnych społeczeństwach zachodnich istnieje niepokojąca tendencja do indywidualizowania kategorii szczęścia, a także do upraszczającego oraz pseudonaukowego posługiwania się zdobyczami psychologii oraz kognitywistki w celach biznesowych. Choć Davies sam nie unika uproszczeń, gdy pisze o wymienionych dyscyplinach, to jednak udaje mu się w przekonujący sposób pokazać ryzyko związane $\mathrm{z}$ pomijaniem polityczno-wspólnotowego wymiaru szczęścia. Prezentuje przy tym ciekawy wycinek utylitarystycznego nurtu w filozofii, pokazując, jak antycypował on współczesny dyskurs dotyczący omawianej przez niego problematyki.
\end{abstract}

Słowa kluczowe: szczęście; psychologia; utylitaryzm; Bentham; Wittgenstein 
Szczęście jest jedną z tych kategorii, które stanowią przedmiot zainteresowania dla przedstawicieli co najmniej kilku różnych dyscyplin naukowych. Jako pierwsi problematykę tę podjęli oczywiście filozofowie. Szczęście było istotnym zagadnieniem zarówno w filozofii starożytnej, jak i w późniejszych okresach, szczególnie w nurcie utylitarystycznym. Współcześnie jednak na temat tej kategorii wypowiadają się również między innymi psychologowie, kognitywiści, socjologowie czy nawet ekonomiści. Pomiary szczęśliwości bywają na przykład wykorzystywane jako alternatywny wobec PKB sposób szacowania sytuacji poszczególnych krajów ${ }^{1}$, co rzecz jasna rodzi ciekawe dyskusje metodologiczno-teoretyczne z pogranicza psychologii oraz socjologii na temat tego, jak w ogóle definiować i mierzyć coś takiego jak szczęście.

William Davies, brytyjski socjolog, ma pełną świadomość tego, że kategoria szczęścia bądź dobrego samopoczucia wykracza poza ramy jednej dyscypliny. Dlatego w jego książce znajdziemy odwołania do każdej z wymienionych w poprzednim akapicie dyscyplin. Od razu należy jednak uprzedzić, że w większości odwołania te nie są przesadnie szczegółowe. Częściowo spowodowane jest to naturalnym ograniczeniem - nie da się w jednej książce omówić dokładnie badań nad tak rozległym zagadnieniem - częściowo zaś popularnonaukową konwencją przyjętą przez Daviesa. Od pierwszej strony widać, że jego celem jest nie tyle wnikanie w szczegóły związane $\mathrm{z}$ dociekaniami nad szczęściem, ale przejrzyste zarysowanie wybranego, politycznego, aspektu problemu - więcej o tym za chwilę. Brak skupiania się na detalach dotyczy w szczególności psychologii oraz kognitywistki. Choć książka zaczyna się od przywołania badań nad mózgiem dotyczących pomiaru szczęścia, to fragment ten ma wymiar głównie anegdotyczny. Davies opisuje w nim eksperyment z udziałem Matthieu Ricarda, biochemika-buddysty, w trakcie którego przy pomocy 256 elektrod badano jego mózg. Ze względu na wyjątkowo pozytywny wynik tych badań media obwołały Francuza najszczęśliwszym człowiekiem na świecie. Kilka lat później Ricard był jednym z czołowych celebrytów zaproszonych na kolejną edycję spotkania w Davos, na którym zbierają się elity światowego biznesu. Przykład ten służy Daviesowi do pokazania, jak w niektórych sytuacjach badania naukowe, przemielone przez upraszczający je dyskurs medialny i przechwycone przez relacje biznesowe, mogą wytwarzać mody o potencjalnie niebezpiecznych konsekwencjach (Davies, 2015, ss. 1-8).

Davies wie, że nie należy rozpatrywać problematyki związanej ze szczęściem w politycznej próżni. Wszak ludzie są szczęśliwi bądź nieszczęśliwi nie w jakiejś nieokreślonej przestrzeni, lecz w ramach konkretnej rzeczywistości

${ }^{1}$ Tego rodzaju badania są wykonywane między innymi w ramach Organizacji Narodów Zjednoczonych oraz OECD. 
polityczno-społecznej. Podobnie jest z badaniami na temat szczęścia - one również odbywają się w ramach określonej otoczki instytucjonalno-finansowej, a nie w oderwanym świecie idei. To właśnie kontekst polityczny jest dla Daviesa najważniejszy - stanowi główny punkt odniesienia w jego książce i nadaje spójność rozważaniom prowadzonym w poszczególnych rozdziałach. Dlatego każda osoba sięgająca po tę publikację powinna mieć świadomość, że ostatecznie jej autora interesują polityczno-społeczne aspekty szczęścia, a nie ściśle naukowy dyskurs, jaki wytworzył się wokół tego zagadnienia.

Nie oznacza to, że mamy do czynienia z książką wyłącznie polityczną. Szczególnie filozofii Davies poświęca dużo miejsca. Robi to przede wszystkim w kontekście historycznym, interesuje go bowiem to, jak wybrani filozofii antycypowali bądź wpływali na dzisiejsze postrzeganie szczęścia. Teza wyjściowa brytyjskiego socjologa jest prosta: „Od czasów rewolucji francuskiej do współczesności (z wyraźnym przyspieszeniem pod koniec XIX wieku) sprzedaje się nam szczególny rodzaj naukowej utopii - podstawowe pytania polityczne i moralne można rozwiązać dzięki odpowiedniej nauce dotyczącej ludzkich uczuć. Propozycje klasyfikowania tych uczyć są oczywiście różne [...] Wzór pozostaje jednak ten sam, nauka na temat subiektywnych odczuć jest przedstawiana jako ostateczny sposób odpowiedzi na pytanie, jak postępować zarówno pod względem moralnym, jaki i politycznym (Davies, 2015, s. 7)”. Ujmując to jeszcze prostszymi słowami, Davies stara się pokazać na licznych przykładach historycznych i współczesnych, jak w ramach interesującej go tradycji filozoficzno-psychologicznej zamiast pytań politycznych dotyczących szczęścia zadawano pytania psychologiczno-indywidualistyczne - zamiast pytać o instytucjonalne warunki dobrobytu danego społeczeństwa, pytano o psychologiczne czynniki wpływające na szczęście pojedynczych ludzi.

Davies zaczyna swoją historię od Jeremy’ego Benthama, słynnego angielskiego filozofa z przełomu XVIII i XIX wieku, którego uważa się za twórcę utylitaryzmu. Bentham pragnął stworzyć podwaliny pod taki system polityczny, który w sposób optymalny będzie maksymalizował szczęście obywateli. Naturalnym problemem, przed jakim stanął, było pytanie, jak mierzyć poziom szczęśliwości. Filozof zaproponował dwie odpowiedzi. Po pierwsze zastanawiał się, czy w określeniu tego, jak bardzo dana osoba jest szczęśliwa, nie mogłoby pomóc mierzenie jej pulsu. Ta kandydatura wydawał się odpowiednia ze względu na jej zakładaną ścisłość i biologiczne podłoże (zdaniem Benthama szczęście było przede wszystkim fenomenem fizycznym). Pod każdym innym względem jednak była rozwiązaniem ułomnym (np. nie wiadomo, jak dokładnie miałoby wyglądać powiązanie między pulsem a szczęściem), co przyznawał sam Bentham. Dlatego zaproponował inną kandydaturę: pieniądze. W jego mniemaniu ilość pieniędzy, jakie są w stanie przeznaczyć ludzie na dany towar bądź usługę, stanowi miarodajną wskazówkę, ile przyjemności sprawiają kupującym określone dobra. Zdaniem Daviesa to połączenie problematyki szczęścia z mechanizmami rynkowymi i pieniędzmi 
było wizjonerskie, bo antycypowało późniejsze próby powiązania tych rzeczy: „wysuwając pogląd, że pieniądze mogą pozostawać w uprzywilejowanej relacji z naszymi wewnętrznymi doświadczeniami, przewyższając tym samym niemal wszystkie inne sposoby pomiaru, Bentham umożliwił połączenie badań psychologicznych z kapitalizmem, które ukształtowało praktyki biznesowe XX wieku" (Davies, 2015, s. 25).

Davies pokazuje, że tego rodzaju podejście było rozwijane między innymi przez Gustava Fechnera, Williama Jevonsa czy Johna B. Watsona. Wszyscy oni zdaniem autora łączyli ze sobą podejście indywidualistyczne, biologistyczne i rynkowe. W konsekwencji tracili sprzed oczu polityczny wymiar zagadnienia szczęścia. Jeśli ktoś martwi się poziomem nierówności społecznych w USA, Wielkiej Brytanii czy gdziekolwiek indziej, popadając z tego powodu w stan depresyjny, to można oczywiście taką osobę zapisać na terapię, dać jej lekarstwa czy zaznajomić z technikami buddyjskiego celebryty. Ale można też, i to podejście zdaniem Daviesa ma większy sens, potraktować jej stan jako wskazówkę, że coś jest nie tak z konstrukcją naszych społeczeństw. Dla jasności - brytyjski socjolog w żadnym razie nie sugeruje, że wszystkie problemy ze szczęściem mają źródła polityczne. Czasami terapia czy leki są najlepszym rozwiązaniem. Rzecz w tym, że w mniemaniu Daviesa mamy do czynienia $\mathrm{z}$ niepokojącą tendencją do zapominania o politycznym wymiarze szczęścia, który gubi się gdzieś między kolejną aplikacją na smartfona, mającą nam pomóc w utrzymaniu wysokiego poziomu zadowolenia, a zalewem coachingu i pseudo-psychologicznych porad.

Davies podaje przykład brytyjskich pracowników, żeby pokazać, jak niebezpieczne jest zarysowane powyżej podejście do szczęścia. Na początek zauważa, że pracodawcy mają poważne podstawy, aby interesować się poziomem zadowolenia swoich podwładnych: „Istnieje oczywista motywacja ekonomiczna dla menadżerów, aby dbali o pozytywne podejście własnych pracowników. Niezliczone badania pokazują, że pracownicy są produktywniejsi, gdy czują się szczęśliwi, prawdopodobnie nawet o 12\%" (Davies, 2015, s. 108). Ten punkt wyjścia wydaje się jeszcze całkiem optymistyczny - to przecież dobrze, że kierownicy muszą interesować się samopoczuciem pracowników, prawda? W neoliberalnej praktyce XXI wieku efekty tego zainteresowania są jednak wysoce niepokojące. Przede wszystkim choć mniej produktywny pracownik jest kłopotem, to jeszcze większy problem stanowi podwładny, który z powodu przykładowo depresji dostał urlop - ponieważ on nie pracuje w ogóle. Dlatego pracodawcy mają dobry powód, aby wmawiać osobom o fatalnym samopoczuciu, że tak naprawdę nadają się do pracy. Brytyjski rząd zatrudnił firmę Atos, aby oceniała zdolność do pracy urzędników - efektem było wiele skandali, gdy firma nakazywała pracować ludziom z poważnymi problemami zdrowotnymi, jak np. uszkodzenie mózgu. 
Kiedy zaś pracodawcy przyznają, że dany pracownik ma problem zdrowotny związany z jego stanem psychicznym, rzadko kiedy sięgają po zbiorowe, polityczne rozwiązania. Zdaniem Daviesa zamiast zadawać pytanie „Co jest nie tak z naszym środowiskiem pracy?”, pytają „Co jest nie tak z daną osobą?”. Istnieje cała gałąź biznesowa - skupiająca coachów, (pseudo)psychologów i innych ekspertów - gotowa udzielić odpowiedzi na drugie z wymienionych pytań. Davies opisuje podejście dwóch tego rodzaju specjalistów, Shawna Achora i Paula Zaka, w następujący sposób: „Szczęście jest wyborem, twierdzi Achor. Możemy albo wybrać bycie szczęśliwym (i odnieść sukces), albo bycie nieszczęśliwym (i ponieść tego konsekwencje). Neurobiolog Paul Zak, inny czołowy mówca i konsultant, sugeruje, że nasze szczęście jest jak mięsień, trzeba je ćwiczyć, aby się rozwinęło. Za tym wysoce zindywidualizowanym podejściem skrywa się tendencja do obwinienia ludzi za nieszczęścia i porażki, które rzekomo wynikają z ich własnych błędów" (Davies, 2015, s. 114). Davies słusznie zauważa, że przy takim nastawieniu szczęście zostaje sprowadzone do czegoś w rodzaju zasobu energii pozwalającego odnieść sukces zawodowy, o który każdy z nas musi osobiście dbać. Mamy więc do czynienia z dwoma rodzajami redukcji: skomplikowana kategoria filozoficzna, jaką jest szczęście, zostaje sprowadzona do roli akumulatora napędzającego nasze sukcesy, natomiast złożone polityczne przyczyny takiego, a nie innego poziomu szczęśliwości w społeczeństwie zostają zastąpione indywidualną odpowiedzialnością każdego z nas.

Nietrudno się domyślić, że rozwiązaniem, jakie proponuje Davies, jest przywrócenie należytej rangi polityce oraz myśleniu społecznemu. Jego zdaniem nie da się rozmawiać o szczęściu jedynie w kategoriach biologicznoindywidualistycznych - w oderwaniu od tego, jak wygląda sytuacja polityczna w danej wspólnocie. Przekonanie Daviesa potwierdza wielu innych badaczy i badaczek, jak choćby Richard Wilkinson i Kate Pickett w wydanym kilka lat temu Duchu równości. Porównywali oni ze sobą dane statystyczne różnych krajów oraz stanów amerykańskich i na tej podstawie stwierdzili silną zależność między poziomem nierówności a zjawiskami takimi jak poziom zaufania, zaburzenia psychiczne, otyłość czy liczba więźniów. Wniosek był prosty i zgodny z obserwacjami Daviesa: nie da się sensownie mówić o żadnym z tych problemów, jeśli nie uwzględnimy sytuacji ekonomiczno-politycznej danego państwa. „Zachęca się ludzi, żeby się dużo ruszali, nie uprawiali seksu bez zabezpieczenia, mówili «nie» narkotykom, starali się zrelaksować, znajdowali równowagę między pracą a życiem prywatnym i spędzali z dziećmi czas $\mathrm{w}$ wartościowy sposób. Jedyne, co łączy wiele z tych polityk, to przekonanie, że biednych trzeba nauczyć bardziej rozsądnego postępowania. Oczywisty fakt, że owe problemy mają wspólne źródło w postaci nierówności dochodów i ubóstwa względnego, jakoś znika z pola widzenia” (Wilkinson, Pickett, 2011, s. 252). Ten fragment z Ducha równości mógłby równie dobrze znaleźć się w książce Daviesa. 
Jeżeli można coś zarzucić Happiness Industry, to z pewnością wybiórcze i pobieżne potraktowanie nauk psychologicznych i kognitywnych. Jak pisałem na początku, jest to naturalna konsekwencja, po pierwsze, przyjęcia konwencji popularnonaukowej, po drugie, skupienia się na aspekcie politycznym. Niemniej jednak efektem ubocznym takiej decyzji jest to, że z książki Daviesa wyłania się wyjątkowo ponura wizja tych dyscyplin, która nie przystaje do rzeczywistości. Choć autor recenzowanej publikacji w żadnym razie nie sugeruje, że psychologia czy kognitywistyka to nauki złe czy niepotrzebne, to jednak ze względu na to, iż przywołuje niemal wyłącznie ich negatywne zastosowania, może niechcący wywołać takie wrażenie w części czytelników. Davies powinien staranniej oddzielać wspomniane dziedziny wiedzy w ich specjalistycznym, naukowym wydaniu od wersji pseudo-naukowych, często skrajnie uproszczonych i dostosowanych do potrzeb biznesu. Udaje mu się to robić między innymi w przypadku filozofii, gdy pokazuje, że w jej ramach istnieją nurty uwzględniające wymiar polityczno-społeczny. Na przykład w pozytywnej części swojej książki, w której Davies sugeruje, jak powinno wyglądać nasze podejście do szczęścia, powołuje się on na filozofię Ludwiga Wittgensteina. Zainspirowany dociekaniami austriackiego myśliciela wygłasza zdanie, które jest dobrą puentą dla rozważań prowadzonych w całej książce. Pisząc o uczuciach innych osób i naszych próbach ich zrozumienia, zaznacza: „Odpowiedź znajduje się nie w głowach czy ciele ludzi, lecz w tym, w jaki sposób wchodzimy z nimi w interakcje" (Davies, 2015, s. 263). To zdanie podsumowuje nie tylko poglądy Daviesa, ale też zalety i wady jego książki. $Z$ jednej strony jest ono upraszczające (wiedza na temat tego, co dzieje się w głowach oraz, szerzej, ciele innych ludzi bywa nader przydatna), z drugiej stanowi ważne przypomnienie: jesteśmy istotami społecznymi i nie możemy zapominać o tym aspekcie naszego życia. Taka przestroga jest szczególnie ważna w czasach, gdy system kapitalistyczny prowadzi do postępującej atomizacji naszych społeczeństw. Dlatego książki takie jak Happiness Industry są ze wszech miar potrzebne.

\section{Literatura}

Davies, W. (2015). The happiness industry: How the government and big business sold us well-being. Londyn, UK: Verso.

Wilkinson, R., Pickett, K. (2011). Duch równości: Tam gdzie panuje równość, wszystkim żyje się lepiej. (P. Listwan, tłum.). Warszawa: Wydawnictwo Czarna Owca. 


\title{
The Happiness Industry. A book review
}

\begin{abstract}
The topic of William Davies's book The Happiness Industry: How the Government and Big Business Sold Us Well-Being is the notion of happiness seen from the philosophical and sociological perspective. The author argues that contemporary western societies have a tendency to individualize happiness and to use psychology and cognitive studies in a simplistic and pseudoscientific manner for business gains. Although there are also some simplifications in Davies's own approach to those disciplines, he is able to show convincingly how risky it is to overlook the political and communal layer of happiness. At the same time he presents an interesting section of the utilitarian current in philosophy by showing how it anticipated modern discourse on happiness.
\end{abstract}

Keywords: happiness; psychology; utilitarianism; Bentham; Wittgenstein 